\title{
Erratum zu: Das Eiszeitalter
}

Die korrigierte Version des Buches ist verfügbar unter $>$ https://doi.org/10.1007/978-3-662-60582-0

https://doi.org/10.1007/978-3-662-60582-0_15

๑) Springer-Verlag GmbH Deutschland, ein Teil von Springer Nature 2021

J. Ehlers, Das Eiszeitalter,

https://doi.org/10.1007/978-3-662-60582-0_16 
Erratum zu: J. Ehlers, Das Eiszeitalter, $>$ https://doi.

org/10.1007/978-3-662-60582-0

Auf den Seiten III und IV wurde die Schreibweise des Vornamens korrigiert.

Auf Seite 372 wurde in der - Abbildung 15.17b (Nordsee) ein falsches Bild eingefügt, und auf Seite 402 fehlen im Literaturverzeichnis die Angaben zu Q und R.
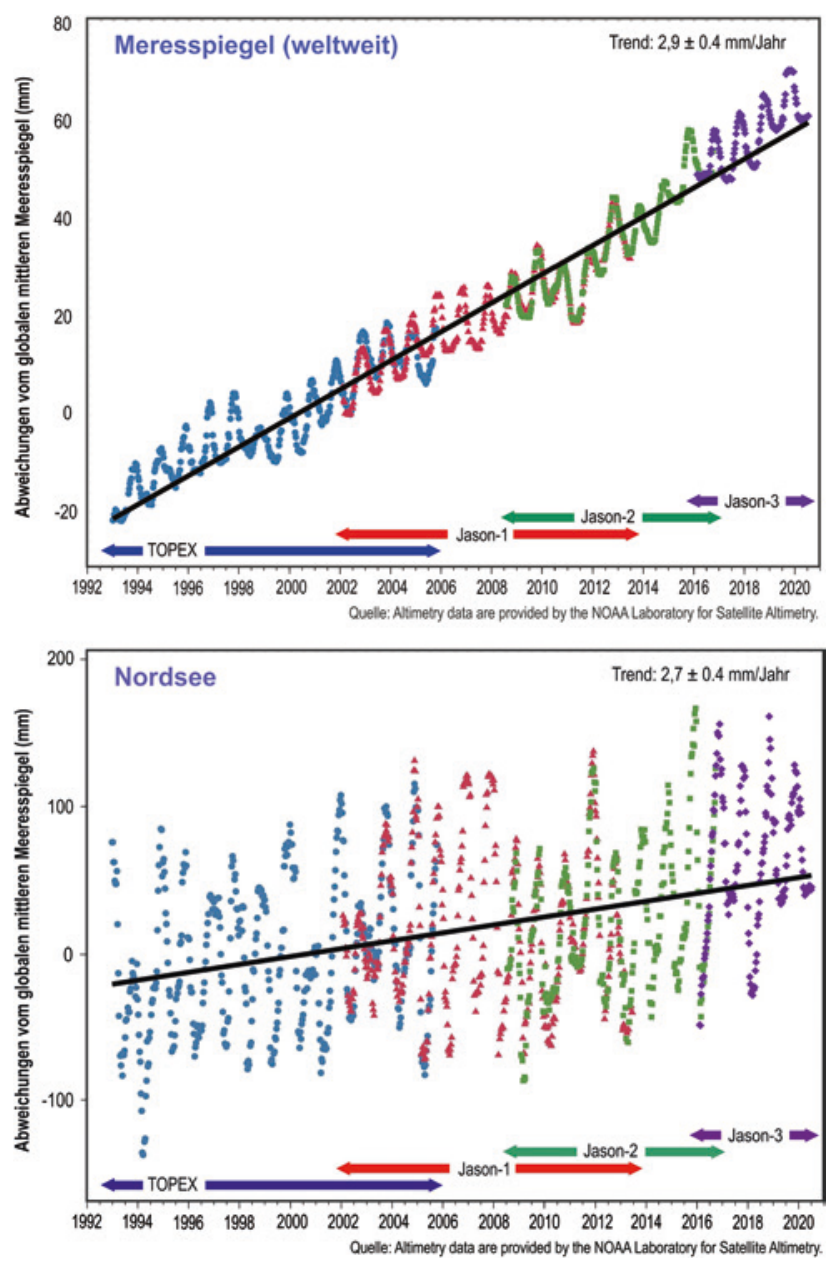

- Abb.15.17 Aktuelle Veränderungen des Meeresspiegels a im Weltmeer, b in der Nordsee. Der Nullwert in den Diagrammen ist willkürlich gesetzt; er entspricht dem Meeresspiegel vom 1. Januar 2000. (Quelle: NOAA) 